\title{
Digitale seksuele delicten in het straf- en strafprocesrecht
}

\author{
Jeroen ten Voorde
}

\section{Inleiding}

Sinds 1886 kent Boek 2 van het Wetboek van Strafrecht (Sr) een aparte titel (XIV) met als opschrift 'Misdrijven tegen de zeden'. De term zeden doet tegenwoordig wat ouderwets aan. Wie de bepalingen in de titel leest, ziet dat met de zeden vooral op de seksuele zeden wordt gedoeld. Strafbaarstellingen van verkrachting, aanranding van de eerbaarheid, verleiding, (kinder)pornografie en dergelijke maken deel uit van titel XIV van Boek 2. Het is daarom wellicht beter om deze zedendelicten seksuele delicten te noemen, zoals in andere strafrechtsstelsels gebruikelijk is. ${ }^{1}$

Tot de seksuele delicten in titel XIV behoren de artikelen 239-251 en de artikelen 254 en 254a Sr. De meeste delicten in titel XIV zijn in de loop der tijd één of meerdere keren gewijzigd. De vele wijzigingen laten zich mede verklaren door telkens veranderende opvattingen over seksualiteit en de taak en rol van de wetgever als het gaat om het reguleren daarvan. Die veranderende opvattingen werden nationaal gevoeld en zijn ook internationaal gevoed door onder andere de Europese Unie en het Europees Verdrag voor de rechten van de mens (EVRM). Bij de totstandkoming van titel XIV was de wetgever beducht zich als zedenmeester op te stellen. Aan het begin van de twintigste eeuw voelde de wetgever zich minder geremd, terwijl aan het eind van de twintigste eeuw uiteenlopende opvattingen kunnen worden onderkend. ${ }^{2}$ Het is wellicht mede dankzij deze wisselende ethische opvattingen en het soms tamelijk hoge tempo waarin wetswijzingen elkaar opvolgden, dat de huidige wettelijke regeling als gevolg van onoverzichtelijkheid en onduidelijkheid door zowel rechtspractici als wetenschappers als knellend wordt ervaren. ${ }^{3}$

De minister van Veiligheid en Justitie heeft zich de kritiek vanuit de rechtspraktijk en -wetenschap aangetrokken. Begin 2016 kondigde de minister in een brief

1 Zie bijv. de Engelse Sexual Offences Act 2003 en Kapittel 26 van het Noorse Wetboek van Strafrecht (getiteld sexuallovbrud, oftewel seksuele misdrijven). In de Franse Code Pénal is een sectie opgenomen met als titel 'Des agressions sexuelles' (section 3, Chapitre II, Titre II, Livre II, Code Pénal). Het Besonderer Teil van het Duitse Strafgezetsbuch heeft een dertiende hoofdstuk getiteld: 'Straftaten gegen die sexuelle Selbtsbestimmung'.

2 J.M. ten Voorde, 'Strafbaarstelling van nieuwe vormen van ongewenste seksuele gedragingen in Nederlandse zedenwetgeving', in: G. van Haegenborgh e.a., Vereniging voor de vergelijkende studie van het recht van België en Nederland. Preadviezen 2016, Den Haag: Boom Juridisch 2016, p. 192-195.

3 K. Lindenberg \& A.A. van Dijk, Herziening van de zedendelicten? Een analyse van Titel XIV, Tweede Boek, Wetboek van Strafrecht met het oog op samenhang, complexiteit en normstelling, Zutphen: Paris 2016. 
aan de Tweede Kamer een 'inhoudelijke modernisering' van de zedenwetgeving aan. Daarbij gaat het niet alleen om een herziening van bestaande strafbepalingen; in de brief wordt tevens overwogen in titel XIV plaats in te ruimen voor een aantal nieuwe fenomenen. De minister constateert namelijk dat een digitalisering van seksuele gedragingen valt waar te nemen waarvoor de strafwetgever niet blind kan en mag zijn:

'Mensen kunnen zich gemakkelijker en steeds anoniemer op het internet begeven. Het gebruik van smartphone en webcam maakt het mogelijk om langs digitale weg (grensoverschrijdend) seksueel gedrag te vertonen of anderen hiertoe aan te zetten. Kinderen beschikken op steeds jongere leeftijd over ICT-apparatuur en groeien op als "digital natives" die een reëel en digitaal leven in elkaar laten overlopen.

Deze ontwikkelingen hebben ertoe geleid dat de kans dat mensen zelf seksueel materiaal genereren en dit laten circuleren of geconfronteerd worden met seksueel materiaal van anderen is toegenomen. Hetzelfde geldt voor de kans dat kinderen worden geconfronteerd met online seksueel handelen van derden, zowel van volwassenen als van leeftijdsgenoten, waarbij al dan niet wordt geprobeerd om kinderen bij dat handelen te betrekken. Het kan hier gaan om experimenteergedrag tussen leeftijdsgenoten, maar ook om handelen dat als maatschappelijk ongepast of niet leeftijdsadequaat kan worden gezien. Een voorbeeld hiervan is het aansporen van kinderen tot het verrichten van seksuele handelingen voor een webcam door volwassenen.'4

De in de brief geschetste ontwikkelingen worden vervolgens nader toegelicht aan de hand van een aantal gedragingen die in de digitale wereld plaatsvinden, namelijk sexting, sexchatting, sextortion en wraakporno. Een omschrijving van deze begrippen volgt verderop in dit artikel. Ten aanzien van sommige van deze fenomenen kondigde de minister in zijn brief aan te onderzoeken in hoeverre aparte strafbaarstelling daarvan wenselijk is. ${ }^{5}$

Deze bijdrage verschijnt naar aanleiding van de door dit tijdschrift georganiseerde en op 25 januari 2018 te houden studiedag over seksuele gedragingen in de digitale wereld. Tijdens deze studiedag worden zij vanuit verschillende invalshoeken besproken: wetgeving, pedagogiek, opsporing, vervolging, berechting en hulpverlening. In deze bijdrage geef ik een overzicht van de wijze waarop in het geldend straf- en strafprocesrecht kan worden gereageerd op of onderzoek kan worden gedaan naar digitale seksuele gedragingen. Het is niet de bedoeling een waardering te geven van het voor deze thematiek relevante huidige straf- en strafprocesrecht; het gaat enkel om een schets van de stand van het recht. Ik zet allereerst uiteen om welke gedragingen het gaat, waarbij ik mij richt op sexting, sexchatting, sextortion en wraakporno. Grooming wordt daarbij slechts zijdelings genoemd. Op virtuele seksuele delicten (bijvoorbeeld grooming met een virtuele 
creatie, virtuele kinderpornografie en seksuele gedragingen tussen virtuele creaties) ga ik in deze bijdrage niet in. ${ }^{6}$ In het op het materiële recht geënte deel van deze bijdrage bespreek ik in hoeverre deze gedragingen reeds strafbaar zijn op grond van het geldende positieve recht. Ik ga in op knelpunten in bestaande wetgeving en reeds geboden oplossingen in vooral jurisprudentie van de Hoge Raad. Vervolgens maak ik een uitstap naar het strafprocesrecht. Ik bespreek de voor de opsporing van seksuele delicten meest relevante bestaande en met de inwerkingtreding van het wetsvoorstel Computercriminaliteit III in te voeren opsporingsbevoegdheden en de mogelijkheden die zij (kunnen) bieden in de aanpak van digitale seksuele delicten en eventuele knelpunten die blijven liggen.

\section{Een overzicht van digitale seksuele gedragingen}

\section{Sexting als overkoepelende term}

Digitale seksuele gedragingen zijn handelingen die op het internet plaatsvinden, meer in het bijzonder op sociale media, zoals WhatsApp, Snapchat, Facebook, Instagram en dergelijke. ${ }^{7}$ Het gebruik van sociale media is de laatste jaren sterk toegenomen. Het Centraal Bureau voor de Statistiek berekende dat in 2015 acht op de tien personen actief waren op een sociaal netwerk zoals Facebook of Twitter. Vooral het uitwisselen van tekstberichten (al dan niet met afbeeldingen) is populair. ${ }^{8}$ Uit onderzoek blijkt voorts dat een flink deel van de jonge gebruikers van sociale media seksueel getinte berichten ontvangt of verstuurt. ${ }^{9}$ Zo kan in tekstberichten worden verwezen naar seksuele handelingen; berichten kunnen ook afbeeldingen (dat wil zeggen foto's of films) van seksuele handelingen bevatten.

Het versturen van seksueel getinte berichten via sociale media vindt plaats tussen verschillende leeftijdsgroepen: tussen minderjarigen en meerderjarigen onderling en tussen minderjarigen en meerderjarigen. In alle gevallen wordt in de literatuur gesproken van sexting. Sexting, een samenvoeging van 'sex' en 'texting', wordt door de minister van Veiligheid en Justitie omschreven als 'het sturen van seksueel getinte berichten of foto's of video's, meestal via de smartphone'. ${ }^{10}$ Hoewel de verwijzing naar texting lijkt te suggereren dat sexting alleen het versturen van geschreven berichten betreft, is de definitie ruimer. Dat valt te begrijpen omdat

6 Zie, met verdere verwijzingen, J. Janssen, 'De stekker eruit? Over de relatie tussen cybercrime en geweld in afhankelijkheidsrelaties', PROCES 2015/5, p. 318-325.

7 E. Lievens, 'Bullying and sexting in social networks: Protecting minors from criminal acts or empowering minors to cope with risky behaviour?', International Journal of Law, Crime and Justice 2014, p. 252.

8 www.cbs.nl/nl-nl/nieuws/2015/27/gebruik-sociale-netwerken-sterk-toegenomen, laatst bekeken op 15 september 2017.

9 E.G. Benotsch e.a., 'Sexting, Substance Use, and Sexual Risk Behavior in Young Adults', Journal of Adolescent Health 2013, p. 307-313; J.R. Agustina \& E.L. Gómez-Durán, 'Sexting: Research Criteria of a Globalized Social Phenomenon', Archives of Sexual Behavior 2012, p. 1325-1328.

10 Kamerstukken II 2015/16, 29279, 300, p. 2; Aanhangsel Handelingen II 2015/16, 1678. Vgl. Lievens 2014, p. 254 met verdere verwijzingen en K. Spooner \& M. Vaughn, 'Youth Sexting: A Legislative and Constitutional Analysis', Journal of School Violence 2016, p. 213. 
digitale texting allang niet meer enkel bestaat uit woorden, maar ook plaatsvindt via het versturen van afbeeldingen. De definitie maakt geen onderscheid tussen minderjarigen en meerderjarigen, al gaat de aandacht in het wetenschappelijk onderzoek en bij de wetgever vooral uit naar sexting tussen minderjarigen en tussen minderjarigen en meerderjarigen. Alles bij elkaar genomen lijkt sexting een tamelijk neutrale term te zijn die verschillende vormen van digitale seksuele communicatie tussen (echte) personen omvat.

\section{Sexchatting}

Sexting kan op verschillende manieren onaangename trekjes krijgen. Dat kan in de eerste plaats door de wijze waarop de communicatie plaatsvindt. De persoon met wie een andere persoon contact heeft, kan op dwingende wijze vragen naar bijvoorbeeld naaktfoto's of de ander vragen zich geheel of gedeeltelijk voor een webcam uit te kleden. In plaats van dwang kan er ook sprake zijn van misleiding of uitlokking. De andere persoon kan ook onverhoeds worden geconfronteerd met vieze praatjes of andere seksueel getinte afbeeldingen. De minister spreekt hier van sexchatting, dat hij omschrijft als 'het op indringende en vergaande seksuele en seksualiserende wijze communiceren via internet'. ${ }^{11}$ Deze omschrijving wijst erop dat niet alle vormen van seksuele communicatie onschuldig zijn. Er kan sprake zijn van het verspreiden van pornografisch materiaal en - in het geval minderjarigen op een bepaalde wijze zijn weergegeven - van kinderpornografische afbeeldingen. De bewoordingen die worden gebruikt kan de ontvanger (buitengewoon) onaangenaam vinden. Ze kunnen gepaard gaan met dwang of bedreiging of met misleiding of uitlokking. Sexchatting kan eenmalig plaatsvinden, maar kan ook aanhoudend van aard zijn. Een bijzondere vorm van sexchatting in de zin van uitlokking van een minderjarige is grooming, oftewel het (digitaal) communiceren met een minderjarige en deze tijdens het gesprek overhalen de ander te ontmoeten, waarbij het doel van de ander is om tijdens die ontmoeting de minderjarige seksueel te misbruiken of daarvan kinderpornografisch materiaal te maken. De grooming is pas voltooid wanneer na het voorstel tot ontmoeting een handeling is verricht die gericht is op het realiseren van de ontmoeting (waarbij het kind seksueel zal worden misbruikt).

\section{Sextortion}

Wanneer de dwang of bedreiging tot doel heeft om 'meer en verdergaand materiaal te leveren', spreekt de minister van sextortion (een samenvoeging van 'sex' en 'extortion'). ${ }^{12}$ Naast sextortion wordt in het Nederlands taalgebied gesproken van seksuele afpersing of seksafpersing. De minister omschrijft dit veelzijdige fenomeen als 'gedrag waarbij seksueel materiaal wordt vergaard waarmee de afgebeelde vervolgens wordt afgeperst (...). Het motief kan gelegen zijn in het verkrij-

11 Kamerstukken II 2015/16, 29279, nr. 300, p. 3.

12 Aanhangsel Handelingen II 2014/15, nr. 933. Zie ook T. Webb, 'The Brave New World of Cyber Crime Investigation and Prosecution', Nexus 2013-2014, p. 82; M. Chawki \& Y. el Shazly, 'Online Sexual Harassment. Issues \& Solutions', Journal of Intellectual Property, Information Technology and E-Commerce Law 2013, p. 76; S. van der Hof, 'Wraakporno op internet. Een verkenning van de (on)mogelijkheden voor een strafrechtelijke aanpak', Ars Aequi 2016, p. 54. 
gen van geld of goederen, meer seksueel materiaal, [of] het verkrijgen van seksuele gunsten.' ${ }^{13}$ Ook 'het uiten van frustratie dan wel het schaden in de eer en goede naam' wordt als motief genoemd. ${ }^{14}$

\section{Wraakporno}

Naast seksuele afpersing bestaat de laatste jaren vrij veel aandacht voor 'revenge porn' of wraakporno. Wraakporno kan worden omschreven als het opzettelijk vernederen van één of meerdere personen door middel van het online posten van naakte afbeeldingen (van die persoon of personen). ${ }^{15} \mathrm{Bij}$ wraakporno gaat het veelal om afbeeldingen van een al dan niet geheel naakte persoon die vrijwillig aan een ander (vaak de partner) zijn gegeven (of door deze zijn gemaakt), die deze op een later moment zonder toestemming van de geportretteerde persoon verspreidt of dreigt te verspreiden, al dan niet tezamen met vernederende beschrijvingen van het slachtoffer. Met het verspreiden van deze afbeeldingen wordt wraak beoogd, bijvoorbeeld vanwege het verbreken van een relatie. ${ }^{16}$

\section{Digitale seksuele delicten in het geldend recht en enkele knelpunten}

\section{Sexchatting in het strafrecht}

Sexchatting, sextortion en wraakporno zijn op grond van het huidige strafrecht niet als zodanig in de wet herkenbaar. Uit rechtspraak blijkt echter dat het geldend recht tot op zekere hoogte deze nieuwe seksuele delicten een plaats geeft in de wet. We bespreken de fenomenen in de besproken volgorde.

Met gesprekken over seks kan worden beoogd de minderjarige over te halen tot een ontmoeting met als doel tijdens die ontmoeting de minderjarige seksueel te misbruiken of daarvan kinderpornografisch materiaal te maken. Wanneer vervolgens enige handeling wordt verricht om de ontmoeting te verwezenlijken, is er sprake van grooming (art. 248e Sr). De rechter stelt geen al te hoge eisen aan de ter verwezenlijking van de ontmoeting te realiseren handelingen: het aandringen op en het noemen van concrete plaatsen voor een ontmoeting, alsmede het uitwisselen van telefoonnummers kunnen voor een bewezenverklaring van dit onderdeel van artikel 248e Sr volstaan. ${ }^{17}$ Wanneer tijdens de gesprekken met een minderjarige aan hem beloften worden gedaan of giften in het vooruitzicht worden gesteld, er sprake is van misbruik van uit feitelijke verhoudingen voortvloeiend overwicht of van misleiding teneinde de minderjarige te bewegen tot ontuchtige handelingen, dan levert dat een poging tot het misdrijf als bedoeld in artikel 248a Sr op. De feitenrechtspraak laat tamelijk veel voorbeelden zien van seksuele

13 Kamerstukken II 2015/16, 29279, nr. 300, p. 3.

14 Kamerstukken II 2015/16, 29279, nr. 300, p. 9; Aanhangsel Handelingen II 2015/16, nr. 3249.

15 S.R. Stroud, 'The Dark Side of the Online Self: A Pragmatist Critique of the Growing Plague of Revenge Porn', Journal of Mass Media Ethics 2014, p. 168.

16 Van der Hof 2016, p. 54; J.K. Stokes, 'The Indecent Internet: Resisting Unwarranted Internet Exceptionalisms in Combating Revenge Porn', Berkeley Technology Law Journal 2014, p. 930.

17 HR 11 november 2014, NJ 2015/73, m.nt. Keijzer. 
gesprekken die een strafbare poging tot verleiding opleverden. ${ }^{18}$ Ook de poging tot feitelijke aanranding van de eerbaarheid (art. 45 jo. art. $246 \mathrm{Sr}$ ) kan bestaan in het voeren van gesprekken waarin de bedreiging met geweld of een andere feitelijkheid al dan niet voltooid was. Bepaalde seksuele gesprekken kunnen blijkens de rechtspraak worden gekwalificeerd als bedreiging (art. $285 \mathrm{Sr}$ ). ${ }^{19}$ Deze kwalificatie kan worden gebruikt wanneer de gedragingen geen poging tot feitelijke aanranding van de eerbaarheid opleveren, bijvoorbeeld omdat de uitvoeringshandelingen onvoldoende in die richting wijzen.

In het geval de gesprekken enige tijd duren, kan er sprake zijn van belaging (art. $285 \mathrm{~b} \mathrm{Sr}$ ). Er is dan voldaan aan de voor die strafbepaling vereiste stelselmatigheid. De gesprekken leveren pas belaging op wanneer ook zij wederrechtelijk opzettelijk inbreuk maken op de persoonlijke levenssfeer. Met wederrechtelijkheid wordt tot uitdrukking gebracht dat niet alle gesprekken onrechtmatig zijn. Dat geldt slechts voor die gesprekken waarvoor geen rechtvaardiging bestaat. De inbreuk op de persoonlijke levenssfeer kan onmiddellijk geschieden (de belaagde wordt rechtstreeks geconfronteerd met de belager), maar ook middellijk (de belaagde is op het moment van de belaging daarvan niet op de hoogte). Stelselmatige seksuele gesprekken met een ander dan de belaagde over de belaagde kunnen belaging opleveren, ook wanneer de belaagde ten tijde van de gesprekken van niets wist. ${ }^{20}$ Kwaadsprekende seksueel getinte roddels over een persoon kunnen daarom strafbaar zijn.

Seksuele gesprekken kunnen ook eenvoudige belediging opleveren (art. $266 \mathrm{Sr}$ ). Daarvoor is vereist dat zij de eer en goede naam van de beledigde aanranden. In het kader van een gesprek geldt dat de belediging in het openbaar of in iemands tegenwoordigheid moet plaatsvinden. Onder omstandigheden kunnen uitlatingen tijdens gesprekken die op zichzelf niet beledigend zijn, toch belediging opleveren op grond van de context waarin de uitlatingen zijn gedaan en in het geval de uitlatingen onnodig grievend zijn oftewel de grenzen van maatschappelijke betamelijkheid overschrijden. ${ }^{21}$

Afgezien van belediging biedt het strafrecht slechts onder omstandigheden ruimte om seksuele gesprekken strafbaar te stellen. ${ }^{22}$ De minister maakt zich vooral zorgen over gesprekken waarbij minderjarigen zijn betrokken. Volgens hem is straffeloosheid daarvan, gelet op (mogelijke) schade aan het (minderjarige) slachtoffer, onwenselijk. ${ }^{23}$

\section{Sextortion in het strafrecht}

Hiervoor noemde ik seksuele afpersing of sextortion een veelzijdig fenomeen. Gelet daarop komen verschillende strafbaarstellingen in aanmerking. Indien het doel van de afperser is gelegen in het verkrijgen van geld of goederen (zoals meer

18 Ten Voorde 2016, p. 236.

19 Ten Voorde 2016, p. 234-235.

20 HR 4 november 2014, NJ 2015/48, m.nt. Reijntjes.

21 Tekst \& Commentaar Strafrecht, aant. 8a bij art. 266.

22 Vgl. K. Lindenberg, 'De strafbaarheid van seksueel getint communiceren met minderjarigen in woord of geschrift. Over sexting, poging tot grooming en andere toenaderingen', DD 2016/4. 
seksueel materiaal in de vorm van foto's of films), ligt het delict afpersing (art. $317 \mathrm{Sr}$ ) voor de hand. Het na bedreiging wegnemen van een op een telefoon of computer opgeslagen afbeelding (van een (gedeeltelijk) naakte persoon) zou wellicht diefstal met bedreiging met geweld kunnen opleveren (art. $312 \mathrm{Sr}$ ). Wordt slechts gedreigd zonder dat een goed wordt afgegeven of weggenomen, dan zou er sprake kunnen zijn van een poging daartoe. Het dreigen met smaad(schrift) of het openbaren van een geheim levert het misdrijf afdreiging op (art. $318 \mathrm{Sr}$ ). Wanneer wordt gedreigd met afbeeldingen van seksuele gedragingen van minderjarigen, kan er sprake zijn van het bezit of (poging tot) het verspreiden van kinderpornografie (art. 240b Sr).

Indien het doel van de afperser is gelegen in het verkrijgen van (meer) seksuele gunsten, wordt in de rechtspraak niet uitgesloten dat wanneer die gunsten op een webcam plaatsvinden ('hands-off') er sprake is van het 'ter beschikking stellen van gegevens' als bedoeld in de artikelen 317 en 318 Sr. ${ }^{24}$ Indien de gunsten 'hands-on' moeten plaatsvinden, zou sprake kunnen zijn van dwang (art. $284 \mathrm{Sr}$ ). Dwang kan onder andere bestaan in het bedreigen met enige feitelijkheid, die bijvoorbeeld zou kunnen bestaan in het dreigen met openbaarmaking van naaktfoto's, teneinde iemand te dwingen tot seksuele handelingen. Voor dwang is enig resultaat vereist; indien dat ontbreekt, biedt de poging (alweer) uitkomst. Overigens valt op basis van rechtspraak van de Hoge Raad niet uit te sluiten dat het dreigen seksueel materiaal te openbaren om meer seksuele gunsten te verkrijgen, te kwalificeren is als voorbereiding van verkrachting of feitelijke aanranding van de eerbaarheid (art. 46 jo. art. 242 respectievelijk art. $246 \mathrm{Sr}$ ). ${ }^{25}$

Het enkele uiten van frustratie als doel van seksuele afpersing lijkt niet strafbaar indien aan de geuite frustratie geen ander doel verbonden is. Wanneer met het uiten van frustratie de eer of goede naam van de ander wordt geschaad, kan sprake zijn van belediging (art. $266 \mathrm{Sr}$ ). Indien de belediging bestaat in (schriftelijke) telastlegging van een bepaald feit met het kennelijke doel daaraan ruchtbaarheid te geven, komt smaad(schrift) of laster (als er sprake is van een leugen) in beeld (art. 261 en $262 \mathrm{Sr}$ ).

De veelzijdigheid van het fenomeen afpersing kan ertoe leiden dat verschillende strafbepalingen in stelling gebracht moeten worden. Dat heeft nadelen. Ten eerste is het denkbaar dat de verschillende doelen die met seksuele afpersing worden beoogd, bestaan uit één feitelijke handeling, waardoor het de vraag is voor welk feit precies moet worden vervolgd. Bij een combinatie van ten laste gelegde feiten (zoals afpersing en poging tot aanranding van de eerbaarheid) kunnen (lastige) samenloopvragen worden gesteld. Ten tweede kan het vervolgen voor (één of meerdere van) de hiervoor genoemde feiten het mogelijk aanwezige specifieke seksuele motief verhullen, terwijl dat motief - dat volgens de minister een schending van de lichamelijke en seksuele integriteit en het seksuele zelfbeschikkingsrecht kan inhouden ${ }^{26}$ - nu juist het centrale verwijt betreft. De constructie via voorbereidingshandelingen kan in de rechtspraktijk als omslachtig worden erva- 
ren, waarbij jegens het slachtoffer en de samenleving de indruk wordt gewekt dat seksuele afpersing slechts een voorbereiding is van het inbreken op de seksuele integriteit, terwijl het slachtoffer van mening kan zijn dat zijn integriteit al is geschonden.

\section{Wraakporno in het strafrecht}

Ook wraakporno valt onder verschillende strafbepalingen. Wanneer de afgebeelde persoon minderjarig is, kan (indien op de afbeelding een seksuele gedraging staat) artikel 240b Sr van stal worden gehaald. Ervan uitgaande dat deze afbeeldingen aanstotelijk zijn voor de eerbaarheid (omdat zij strijdig zijn met de voor de grote meerderheid van de samenleving heersende zeden), is strafbaarheid op grond van de artikelen 239 en 240 Sr eveneens denkbaar. Ze kunnen ook schadelijk zijn te achten voor kinderen jonger dan 16 jaar, waardoor artikel 240a Sr in beeld komt. Het uit wraak online plaatsen van pornografische afbeeldingen van meerderjarigen lijkt niet strafbaar op grond van deze bepalingen, tenzij ze zichtbaar zijn of worden vertoond aan kinderen jonger dan 16 jaar (art. 239 aanhef onder $2^{\circ} \mathrm{Sr}$ en art. 240a Sr). Meerderjarigen die het slachtoffer worden van wraakporno kunnen klacht doen van smaad(schrift) (art. $261 \mathrm{Sr}$ ). ${ }^{27}$ Zonder telastlegging van een bepaald feit zal smaad(schrift) echter niet kunnen worden bewezen. Dat beperkt het gebruik van artikel 261 Sr in niet onbelangrijke mate; het plaatsen van een foto uit wraak voor het beëindigen van een relatie hoeft nog geen telastlegging van een feit in te houden, in ieder geval niet wanneer het plaatsen of verspreiden van foto's zonder enige toelichting geschiedt.

Hoogstwaarschijnlijk treedt over enige tijd artikel 138c Sr in werking. ${ }^{28}$ Dat stelt strafbaar het opzettelijk en wederrechtelijk voor zichzelf of een ander overnemen van niet-openbare gegevens die zijn opgeslagen door middel van bijvoorbeeld een computer. De bepaling zou volgens de minister ook kunnen worden gebruikt tegen wraakporno. ${ }^{29}$ Zij lijkt daarvoor echter slechts ten dele geschikt. Een persoon die al in het bezit is van een afbeelding en deze afbeelding vervolgens uit wraak openbaar maakt, zal op grond van het voorgestelde artikel 138c Sr niet strafbaar zijn. Het nieuwe kabinet lijkt zich van de beperkingen van artikel $138 \mathrm{c}$ $\mathrm{Sr}$ bewust. In het regeerakkoord wordt aangekondigd dat het verspreiden van wraakporno als zelfstandig delict strafbaar wordt gesteld. Reden voor deze strafbaarstelling is het belang dat wordt gehecht aan "het beschermen van de privacy van burgers onderling. ${ }^{30}$ In hoeverre onder het verspreiden ook het openbaar maken wordt verstaan, moet worden afgewacht. 


\section{Opsporing en vervolging van digitale seksuele delicten}

\section{Het beleid van het Openbaar Ministerie in zedenzaken}

Strafrechtelijk onderzoek naar digitale seksuele delicten vereist een grote mate van zorgvuldigheid en voorzichtigheid. ${ }^{31}$ In de 'Aanwijzing kinderpornografie' wordt bijvoorbeeld aangegeven dat bepaalde gedragingen met wederzijdse toestemming van betrokkenen plaatsvinden. In dat geval is de vraag of strafrechtelijk optreden opportuun is, ook als er sprake is van minderjarigen. De Hoge Raad onderschrijft dat in geval van consensus tussen betrokkenen strafbaarheid van het bezit van kinderporno kan ontbreken. ${ }^{32}$ Waar consensus ontbreekt of op enig moment een van de betrokkenen niet meer instemt met het gedrag, kan er sprake zijn van schade. In het laatste geval moet soms worden afgevraagd waarom de consensus is ingetrokken; de grens tussen dader en slachtoffer is niet altijd eenvoudig te trekken, zeker niet wanneer de leeftijd tussen beiden niet groot is. In dat geval 'moet goed worden afgewogen of de inzet van het strafrecht de juiste vorm is om deze schade te beperken en/of te herstellen. Alternatieve mogelijkheden, zoals het bijsturen van (internet)gedrag of het voorlichten van minderjarigen en/of hun ouders, kunnen in bepaalde gevallen beter effect sorteren.' Indien sprake is van dwang, pesten of chanteren, van een groot leeftijdsverschil tussen betrokkenen (waarvan de minderjarige niet op de hoogte is) of van het verspreiden van materiaal, is voor het Openbaar Ministerie '[l]eidend criterium bij de afweging of vervolging is aangewezen, (...) de schade die is berokkend aan de afgebeelde minderjarige en het belang van deze minderjarige (en eventuele andere betrokkenen)'. ${ }^{33}$

In de 'Aanwijzing zeden' maakt het Openbaar Ministerie een aantal opmerkingen die ook voor digitale seksuele delicten van belang zijn. ${ }^{34}$ Opnieuw worden zorgvuldigheid en voorzichtigheid benadrukt, niet alleen ten behoeve van het slachtoffer, maar ook omdat lang niet alle gedragingen een seksueel delict inhouden en een onterechte beschuldiging forse implicaties kan hebben voor de persoon die wordt beschuldigd. 'In zedenzaken is daarom uiterst belangrijk dat zorgvuldig onderzocht en zo precies mogelijk vastgesteld wordt wat er is gebeurd en dat conclusies pas daarna worden getrokken.' Voor de opsporing heeft dit uitgangspunt bepaalde consequenties. Zo worden onder meer genoemd het zo veel mogelijk afzonderlijk horen van aangevers en (andere) getuigen, het krijgen van een goed beeld van soms 'uiterst complexe context' waarin de feiten zich kunnen hebben afgespeeld, het waarborgen van de 'directe veiligheid van betrokkenen en ande-

31 In deze paragraaf richt ik mij enkel op opsporing en vervolging. Nodeloos te vermelden is dat seksuele delicten ook tijdens de berechtingsfase met de vereiste voorzichtigheid en zorgvuldigheid worden behandeld. Deze eisen zijn onder andere vertaald in bewijsminima, zoals onder meer geformuleerd in art. 342 lid 2 Sv (eenvoudig gezegd: één getuige is geen getuige). Voor het slachtoffer kan het spreekrecht van groot belang zijn, terwijl de getuigenregeling van de art. $263 / 264$ en $287 / 288$ Sv mede zo is ingericht dat een slachtoffer van een seksueel delict niet als getuige aan een pijnlijke ondervraging door de verdediging hoeft te worden onderworpen.

32 HR 9 februari 2016, NJ 2016/257.

33 Aanwijzing kinderpornografie 2016A005, Stcrt. 2016, 19415, par. 1.4.

34 Aanwijzing zeden 2016A004, Stcrt. 2016, 19414, par. 1-2. 
ren', het zo veel mogelijk voorkomen van zogeheten 'secundaire victimisatie' van het slachtoffer, en het in ogenschouw nemen 'of strafrechtelijke interventie bijdraagt aan het vergroten van de veiligheid en het beperken van recidivekansen'. Tevens wordt in de Aanwijzing opgemerkt dat aangifte van een zedendelict in beginsel eerst leidt tot een 'informatief gesprek tussen de politie en de melder'. ${ }^{35}$ $\mathrm{Na}$ het gesprek wordt de melder bedenktijd gegund voor het doen van aangifte. In het geval het feit of de feiten zich hebben afgespeeld op sociale media, meldt de 'Aanwijzing zeden' dat onderzoek naar gegevensdragers moet worden gedaan.

\section{Strafvorderlijke bevoegdheden in de digitale wereld}

Voor onderzoek naar gegevensdragers zijn verschillende bevoegdheden in het Wetboek van Strafvordering (Sv) opgenomen. Deze staan vermeld in afdeling 7 van titel IV en de in afdeling 7 en 8 van titel IVA van Boek 1 van het Wetboek van Strafvordering. ${ }^{36}$ Afdeling 7 van titel IV regelt niet alleen de bevoegdheid voor de rechter-commissaris, de officier van justitie, de hulpofficier en de opsporingsambtenaar tot doorzoeking van plaatsen waar zich een gegevensdrager bevindt (denk ook aan een smartphone of tablet), ${ }^{37}$ maar ook de bevoegdheid om de zich op die gegevensdrager bevindende gegevens vast te leggen indien dat in het belang van het onderzoek is (art. 125i Sv). ${ }^{38}$ Tevens is het in bepaalde gevallen mogelijk om vanaf een plaats waar de doorzoeking geschiedt onderzoek te doen naar gegevens die zijn opgeslagen op een computer die zich niet bevindt op de plaats van de doorzoeking. Aangetroffen gegevens mogen worden vastgelegd (art. 125j Sv). Indien de computer met een wachtwoord of door versleuteling (encryptie) is beveiligd, kan aan de persoon van wie redelijkerwijs kan worden vermoed dat hij het wachtwoord of de wijze van versleuteling kent, het bevel worden gegeven toegang tot de computer te verschaffen, of een deel daarvan (art. 125k lid 1 en $2 \mathrm{~Sv}$ ). Aan het bevel het wachtwoord te geven moet gehoor worden gegeven (art. 125k lid 1 laatste volzin Sv), behalve door de verdachte (lid 3) die zichzelf niet hoeft te incrimineren (nemo-teneturbeginsel). In gegevensdragers aangetroffen gegevens kunnen ontoegankelijk worden gemaakt. Op die manier worden onder meer gebruikmaking en verspreiding van deze gegevens onmogelijk (art. 125o Sv).

Andere opsporingsbevoegdheden die relevant kunnen zijn, vinden we in afdeling 7 en 8 van titel IVA van Boek 1 van het Wetboek van Strafvordering. Het gaat dan bijvoorbeeld om het opnemen van vertrouwelijke communicatie, al dan niet met een technisch hulpmiddel (art. 1261 en 126m Sv). Met deze bevoegdheden kun-

'Het informatief gesprek dient enerzijds om de melder te informeren over de gevolgen van het doen van aangifte en de mogelijke impact van het strafrechtelijke traject. Daarnaast wordt informatie gegeven over de mogelijkheden van hulpverlening, slachtofferrechten en juridische bijstand. Anderzijds wordt op basis van de inhoud van het gesprek door politie en openbaar ministerie afgewogen of strafrechtelijk optreden aangewezen is en zo ja op welke wijze' (Aanwijzing zeden, par. 2.1).

36 Bevoegdheden vermeld in titel $\mathrm{V}$ en $\mathrm{VB}$ worden hier niet besproken.

37 Zie ook B.-J. Koops, C. Konings \& F. Verbruggen, Zoeken in computers naar Nederlands en Belgisch recht. Welke plaats hebben 'digitale plaatsen' in de systematiek van opsporingsbevoegdheden? (preadvies Nederlands-Vlaamse Vereniging voor Strafrecht), Oisterwijk: Wolf Legal Publishers 2016, p. 24.

38 Art. 80quinquies Sr geeft een omschrijving van gegevens. 
nen seksuele gesprekken worden opgenomen die van belang kunnen zijn om te bepalen wat met die gesprekken wordt beoogd (bijvoorbeeld van belang in het kader van grooming of poging tot verleiding), in hoeverre sprake is van stelselmatigheid (van belang in het kader van belaging) of wat precies wordt gezegd (bijvoorbeeld van belang in het kader van belediging). In deze titel vinden we ook de bevoegdheid om verkeersgegevens of gebruikersgegevens te verstrekken (art. 126n en 126na Sv). Dat kan bijdragen aan het onderkennen van de persoon van de verdachte. Deze bevoegdheden betreffen overigens niet alleen telefoongesprekken. De wet kent ook een bevoegdheid e-mailberichten en chatgesprekken te vorderen (art. 126ng Sv), waarbij net als in artikel 125k lid 2 Sv degene van wie redelijkerwijs kan worden vermoed dat hij kennis draagt van de wijze van versleuteling, medewerking kan worden bevolen om de versleuteling ongedaan te maken (uitgezonderd de verdachte). Gegevens die in het bijzonder vatbaar zijn voor verlies of wijziging kunnen onder bepaalde voorwaarden voor een bepaalde duur (maximaal 90 dagen) worden bevroren (art. 126ni Sv).

\section{Problemen in de bestaande wetgeving}

In het wetsvoorstel Computercriminaliteit III wordt een aantal knelpunten in de digitale opsporing genoemd die ook de opsporing van digitale seksuele delicten kunnen belemmeren. De eerste is dat veel digitale communicatie wordt versleuteld. Dat doen personen ofwel zelf met behulp van eenvoudig op internet te downloaden versleutelingsprogramma's, ofwel voorzien aanbieders van een communicatiedienst daarin (zoals Twitter). Op die manier kunnen teksten ontoegankelijk worden. Tevens is het tegenwoordig mogelijk dat telefoon- en ander communicatieverkeer (e-mail, WhatsApp) is versleuteld, zodat een tap weinig zal opleveren. De aanbieder van een communicatiedienst is weliswaar verplicht mee te werken aan het ongedaan maken van de versleuteling van de communicatie (art. 126 lid 6 en art. 126nh lid 1 Sv), maar de aanbieder is daartoe soms niet in staat, of de versleuteling is complex (want gaat over verschillende lagen, waarbij telkens een andere aanbieder betrokken is), of de aanbieder bevindt zich in het buitenland. De wetgever wijst erop dat rechtshulpverzoeken lange tijd in beslag nemen en niet bij voorbaat succesvol zijn. ${ }^{39}$ Ten tweede vindt communicatie tegenwoordig vaak plaats via draadloze netwerken (wifi), wat het tappen sterk bemoeilijkt, tenzij een tap bij alle aanbieders van een communicatiedienst wordt geplaatst. Dat staat echter op gespannen voet met het proportionaliteitsbeginsel. ${ }^{40}$ Ten derde worden gegevens tegenwoordig steeds vaker opgeslagen in de zogeheten cloud, bijvoorbeeld Dropbox. Opsporing wordt daardoor bemoeilijkt, omdat niet duidelijk is waar alle informatie zich bevindt (en in welke landen), terwijl cloudcomputingdiensten soms anonimiteit van klanten garanderen, zodat niet duidelijk is bij welke dienst gegevens moeten worden gevorderd. De wet biedt weliswaar mogelijkheden onderzoek te doen op cloudcomputingdiensten (via een zogeheten netwerkzoeking), maar het daarvoor te gebruiken artikel 125j Sv kent verschillende beperkingen en onduidelijkheden: andere gegevensdragers dan compu- 
ters mogen niet worden doorzocht, de doorzoeking mag enkel plaatsvinden vanaf de plaats waar de doorzoeking wordt gedaan, en de netwerkzoeking is 'beperkt tot situaties van een doorzoeking' ${ }^{41}$ Artikel $125 j$ Sv wordt daarom wel als knellend ervaren.

\section{Het wetsvoorstel Computercriminaliteit III ${ }^{42}$}

Vanwege de gesignaleerde moeilijkheden wordt voorgesteld opsporingsambtenaren de bevoegdheid te geven om een geautomatiseerd werk te hacken (art. $126 \mathrm{nba}$ Sv). Hacken is het op afstand heimelijk binnendringen van een geautomatiseerd werk teneinde vervolgens bepaalde opsporingshandelingen te kunnen verrichten (zoals het traceren van (de locatie en persoonsgegevens van) de gebruiker). Deze nieuwe bevoegdheid heeft veel aandacht gekregen, ook in de literatuur. ${ }^{43}$ De wetgever lijkt haar als een volgende stap te zien in het arsenaal van bevoegdheden dat reeds bestaat, een stap die de hiervoor gesignaleerde problemen zou helpen oplossen. De bevoegdheid van artikel 126nba kan worden toegepast in geval van verdenking van een misdrijf als omschreven in artikel 67 lid $1 \mathrm{~Sv}$ dat, gezien zijn aard of samenhang met andere door de verdachte begane misdrijven, een ernstige inbreuk op de rechtsorde oplevert. In dat geval kan de officier van justitie, indien het onderzoek dit dringend vordert, een opsporingsambtenaar bevelen binnen te dringen in een geautomatiseerd werk dat bij de verdachte in gebruik is. Daarbij kan gebruik worden gemaakt van een technisch hulpmiddel. De computer hoeft niet van de verdachte te zijn (hij kan ook van de ouders, vriend(in) of huisgenoot zijn) en het gebruik is plaatsonafhankelijk. De bepaling maakt ook hacken in een (cloud)server mogelijk. De toepassing is beperkt tot het bereiken van bepaalde doelen, waaronder de vaststelling van de identiteit van de gebruiker of de locatie van het geautomatiseerde werk en de uitvoering van het bevel als bedoeld in de artikelen $126 \mathrm{l}$ en $126 \mathrm{~m}$ Sv (het opnemen van vertrouwelijke informatie respectievelijk het opnemen van communicatie met een technisch hulpmiddel). De hackbevoegdheid kan ook het vastleggen van opgeslagen gegevens of het ontoegankelijk maken van gegevens inhouden in geval van een misdrijf waarop naar de wettelijke omschrijving acht jaar of meer gevangenisstraf is gesteld (dan wel een bij algemene maatregel van bestuur aangewezen misdrijf). De bevoegdheid kan voor vier weken worden ingezet en is telkens met vier weken

41 Kamerstukken II 2015/16, 34372, 3, p. 10-12; Koops, Konings \& Verbruggen 2016, p. 35-40.

42 Zie voor een helder overzicht van de voorstellen: J.J. Oerlemans, 'De wet computercriminaliteit III: meer handhaving op internet', Strafblad 2017, p. 350-359. Ik bespreek in het navolgende niet het gehele wetsvoorstel. De nieuwe regeling Notice and Take Down (art. 125p (nieuw) Sv) laat ik buiten beschouwing. Die regeling kan wel relevant worden in de aanpak van digitale seksuele delicten. Het Openbaar Ministerie kan met de nieuwe bevoegdheid een internetdienst verplichten bepaald strafbaar materiaal (zoals afbeeldingen met een seksuele strekking) te verwijderen. De regeling is met verschillende waarborgen omkleed. Zo is een machtiging van de rechter-commissaris vereist.

43 J.J. Oerlemans, Investigating cybercrime (diss. Leiden), Waddinxveen: Amsterdam University Press 2017, p. 249-291; J.J. Oerlemans, 'Hacken als opsporingsbevoegdheid', DD 2011, p. 888-908; R.L.D. Pool \& B.H.M. Custers, 'The Police Hack Back: Legitimacy, Necessity and Privacy Implications of the Next Step in Fighting Cybercrime', European Journal of Crime, Criminal Law and Criminal Justice 2017, p. 12-144; Koops, Konings \& Verbruggen 2016, p. 49-62. 
verlengbaar. De bevoegdheid behoeft toestemming van de rechter-commissaris en moet vooraf worden voorgelegd aan de Centrale Toetsingscommissie, een adviesorgaan van het Openbaar Miniserie.

Een bevoegdheid die niet in het Wetboek van Strafvordering maar in het Wetboek van Strafrecht wordt opgenomen, is het gebruik van een (virtuele) lokpuber op internet om te zoeken naar personen die met minderjarigen in contact willen treden en daarmee seksuele gesprekken willen voeren of hen willen overhalen tot seksuele gedragingen, al dan niet op internet. De lokpuber is een opsporingsambtenaar, een ouder, een oudere broer of zus of een oudere vriend of vriendin van een minderjarige die zich op chatsites als minderjarige voordoet en met meerderjarigen in contact treedt teneinde hun identiteit te achterhalen. Enkele jaren geleden deed de virtuele lokpuber zijn intrede in de vorm van de voor Terre des Hommes ontwikkelde Sweetie, die op chatsites werd ingezet teneinde de omvang van sexchatting tussen minder- en meerderjarigen in kaart te brengen. Wanneer de (virtuele) lokpuber te actief is in het zoeken van contact met meerderjarigen en hen brengt tot andere handelingen dan waarop zijn opzet reeds tevoren was gericht (en de beginselen van proportionaliteit en subsidiariteit zijn geschonden), is het inzetten van deze opsporingsmethode niet toegestaan (Talon-criterium). ${ }^{44}$ De wetgever beoogt met de wijziging van artikel 248e Sr niet alleen de reikwijdte van de bepaling gevoelig op te rekken, maar ook het gebruik van de lokpuber toe te laten, zolang het Talon-criterium niet wordt geschonden. Strafbaar wordt ook het groomen van een niet-minderjarige persoon zonder dat de groomer daarvan ten tijde van het groomen op de hoogte is. De niet-minderjarige persoon kan ook een 'virtuele creatie' zijn. Omdat ook het groomen van een ander dan een minderjarige strafbaar wordt gesteld, wordt via een omweg het gebruik van een ander dan een minderjarige in de opsporing van grooming mogelijk gemaakt. ${ }^{45}$

\section{Opsporingsbevoegdheden en nieuwe seksuele delicten}

Welke van de hiervoor besproken opsporingsbevoegdheden kunnen tegen welke seksuele delicten worden ingezet? We zagen dat sexchatting als zodanig onder voorwaarden slechts strafbaar is, namelijk wanneer een bepaald doel wordt beoogd (bijvoorbeeld art. 248a en 248e Sr en art. 285b Sr), wanneer de bewoordingen de eer en goede naam aantasten (art. $266 \mathrm{Sr}$ ) of wanneer sprake is van bedreiging (art. $285 \mathrm{Sr}$ ). Deze delicten zijn alle misdrijven. Verdenking van de misdrijven genoemd in de artikelen 246 en 248a Sr levert een geval van voorlopige hechtenis op (art. 67 lid 1 sub a Sv). Hetzelfde geldt voor de misdrijven genoemd in de artikelen 248e, 285 en 285b Sr (zie art. 67 lid 1 sub b Sv).

De misdrijven die werden genoemd bij sextortion, leveren bijna alle een geval van voorlopige hechtenis op. ${ }^{46}$ Hieruit volgt dat verschillende van de hiervoor besproken opsporingsbevoegdheden kunnen worden toegepast. Daarbij geldt ten aanzien van sommige bevoegdheden de bijkomende eis dat de misdrijven een inbreuk

44 Zie S.F.J. Smeets, 'De “lokpuber”: een mislukt experiment', Strafblad 2013, p. 332-338.

45 Zie over virtuele grooming nader: J.M. ten Voorde, 'Schade in de virtuele wereld: de casus virtuele grooming', Netherlands Journal of Legal Philosophy 2017/3.

De art. 261 en 262 Sr vormen hierop een uitzondering. 
op de rechtsorde moeten opleveren. Deze eis lijkt een minder grote drempel op te werpen dan op het eerste gezicht wellicht kan worden gedacht. ${ }^{47}$ Met name wanneer het gaat om delicten tegen minderjarigen zou deze drempel wel eens snel kunnen worden gehaald.

Bij wraakporno is de toepassing van de hiervoor genoemde bevoegdheden nauwelijks mogelijk. De misdrijven genoemd in de artikelen 239, 240 en 138c Sr leveren geen geval van voorlopige hechtenis op. Alleen wanneer de verstuurde afbeeldingen vallen onder artikel 240b Sr kunnen meerdere opsporingsbevoegdheden worden ingezet. In hoeverre de in het regeerakkoord voorgestelde strafbaarstelling van het verspreiden van wraakporno een ruime inzet van opsporingsbevoegdheden mogelijk zal maken, moet worden afgewacht. In het regeerakkoord wordt daarover niets bijzonders aangegeven.

Een voorzichtige conclusie, gelet op het geldend recht, zou daarom kunnen zijn dat de strafrechtelijke aanpak van wraakporno wordt bemoeilijkt door het niet kunnen inzetten van de hier genoemde digitale opsporingsmethoden. Bij sextortion en sexchatting zouden problemen kunnen ontstaan wanneer de gedragingen 'slechts' de eer en goede naam van de ontvanger aantasten. De toepassing van verschillende opsporingsmethoden in het digitale terrein lijkt dan uitgesloten. In andere gevallen is de toepassing van de besproken opsporingsbevoegdheden niet zonder meer uitgesloten. Ten aanzien van alle digitale seksuele delicten geldt echter het uitgangspunt dat het onderzoek daarnaar met de nodige voorzichtigheid en zorgvuldigheid moet plaatsvinden.

\section{Slotopmerkingen}

Deze bijdrage is niet bedoeld een oordeel te geven over mogelijke strafbaarstelling van verschillende nieuwe digitale seksuele gedragingen. Ten aanzien van sexchatting, sextortion en wraakporno is slechts geïnventariseerd onder welke strafbaarstellingen deze gedragingen in het geldend recht zouden kunnen vallen. Tevens zijn enkele (mogelijke) knelpunten in de bestaande wetgeving genoemd. In hoeverre die knelpunten zo groot zijn dat aparte strafbaarstelling wenselijk is en hoe die eventuele strafbaarstellingen er dan uit zouden moeten zien, is niet aan de orde gekomen. De wenselijkheid van aparte strafbaarstelling vereist onderzoek naar verschillende onderwerpen: de impact van deze gedragingen op het leven van personen (is er sprake van schade of gevaar voor schade?), de afweging van in het geding zijnde rechtsbelangen (bescherming van personen versus bijvoorbeeld vrijheid van meningsuiting of de mogelijkheid dat jonge mensen vanaf een bepaalde leeftijd en tot op zekere hoogte mogen experimenteren met seks), de relevantie van het verschil tussen meerderjarigen en minderjarigen (moeten eventuele strafbaarstellingen zich tot minderjarige slachtoffers beperken?), maar ook de vraag of dergelijke fenomenen wel via het strafrecht moeten worden aangepakt (strafrecht als ultimum remedium) en of het strafrecht wel de meest passende oplossing kan bieden (strafrecht als optimum remedium). Daarbij is een 
eenzijdige blik op het materiële recht niet voldoende. Tevens zal zorgvuldig moeten worden bezien welke bevoegdheden nodig en gepast zijn in de opsporing van deze fenomenen. De wet kent verschillende bevoegdheden, en nieuwe zijn op komst. Zijn de belangen die met de aanpak van digitale seksuele delicten zo groot dat zij de inbreuk op de persoonlijke levenssfeer van vele personen (onder wie de verdachte) rechtvaardigen? Die vraag zal door de wetgever bij het opstellen van een nieuwe regeling onder ogen moeten worden gezien. Alles overziende is het voor hem een hele kluif om een 'inhoudelijke modernisering' van de zedenwetgeving van de grond te krijgen.

Daarbij kan nog het volgende worden opgemerkt. Opsporing in het digitale domein vereist de nodige cyberkennis. $\mathrm{Zij}$ is met de opkomst van internet en alle mogelijkheden die dat biedt bepaald complexer geworden. Die complexiteit speelt politie en justitie al jaren parten. Er wordt weliswaar geïnvesteerd in de aanpak van cybercriminaliteit, waarbij ook de digitale seksuele delicten worden betrokken, maar de investeringen hebben nog niet altijd het gewenste resultaat. Er bestaat een gebrek aan in cybercrime gespecialiseerde officieren van justitie, en de cyberkennis bij de Nationale Politie schiet tekort. ${ }^{48}$ Bij de zittende magistratuur liggen de zaken vermoedelijk niet veel anders. Deze tekorten worden op het hoogste niveau onderkend: in de rijksbegroting voor het jaar 2018 worden extra middelen vrijgemaakt om cybercrime aan te pakken, ${ }^{49}$ en het nieuwe kabinet wil meer investeren op het terrein van cybersecurity. De vraag is of cybercrime voldoende strafrechtelijk kan worden aangepakt, ook gelet op de binnen de genoemde organisaties zelf gesignaleerde gebreken. Dan is het ook de vraag of nieuwe wetgeving de rechtspraktijk zal helpen wanneer de praktische problemen niet tegelijkertijd worden opgelost. 